\title{
Patterns of idiopathic nephrotic syndrome in Upper Egyptian children
}

\author{
Ghada Ashry B. Abd-Elrehim ${ }^{1}$, Ali Abo-Elmagd Ahmed MD', Swsan Abd Al- \\ Monium Fadda $\mathrm{MD}^{2}$, Safaa Husein Ali MD ${ }^{1}$, Naglaa Fawzy Ahmed MD \\ ${ }^{1}$ Pediatric Department, Sohag University Hospital, Sohag University, Sohag, Egypt \\ ${ }^{2}$ Pathology Department, Qasr El Eyni Hospital, Cairo University, Cairo, Egypt
}

\begin{abstract}
Background and aim of work: Idiopathic nephrotic syndrome (INS) is a common and important chronic kidney disease in childhood. Steroid response pattern and the underlying histopathological spectrum of INS show variabilities in the different geographical regions. This work aimed to highlight the clinical profile, steroid response pattern and histopathological spectrum of INS in our locality in Sohag, Upper Egypt.

Patients and Methods: A prospective study included 77 children with INS aged from 1-15 years followed for at least one year, diagnosed and treated at our pediatric nephrology unit in the period from January 2010 to December 2014 was done. The patients' demographic features, clinical profile, steroid response pattern and the underlying histopathological spectrum were studied.

Results: Total included patients were 77 children. The mean age at disease onset was $4.87 \pm 2.94$ (range 1.5-15) years. Male/female ratio was 1.6/1. Steroid was given to all patients, $79.2 \%$ of patients had steroid sensitive nephrotic syndrome (SSNS), while $20.8 \%$ had steroid resistant nephrotic syndrome (SRNS). Out of 61 steroid sensitive patients, about 54\% developed either steroid dependent nephrotic syndrome (SDNS) or frequently relapsing nephrotic syndrome (FRNS). Biopsy was done in $33.8 \%$ of patients and revealed focal segmental glomerulosclerosis (FSGS) in $42 \%$, minimal change disease (MCD) in 39\% and mesangio-proliferative glomerulonephritis (MesPGN) in 19\% of patients. End stage renal disease (ESRD) developed in 1 patient with SRNS and FSGS.
\end{abstract}

Conclusion: About eighty percent of our patients were steroid sensitive but more than half of them had SDNS or FRNS. The main histopathological pattern seen in renal biopsies was FSGS.

Key words: Idiopathic nephrotic syndrome, steroid response and focal segmental glomerulosclerosis.

\section{Introduction}

Nephrotic syndrome (NS) is one of the most common chronic renal diseases in children. ${ }^{1}$ It has an incidence of 2-16.9 per $\mathbf{1 0 0 . 0 0}$ children worldwide $^{2}$. Idiopathic nephrotic syndrome is the most common form of NS in childhood representing about $\mathbf{9 0 \%}$ of all cases and it is composed of NS and primary glomerular disease without an identifiable causative disease or infection. ${ }^{3}$ Up to $\mathbf{8 5 \% - 9 0 \%}$ of children with INS are steroid sensitive, but follow a relapsing and remitting course in the majority of cases. $^{4}$ About half of those who relapse, show frequently relapsing or steroid dependent course. ${ }^{5}$ The underlying histopathological characteristics of INS are of immense significance in determining steroid responsiveness and long-term prognosis. ${ }^{6}$ The majority of children with INS have MCD which is generally responsive to steroid, so 
renal biopsy is indicated in patients suspected to have histological types other than MCD. ${ }^{7}$ Idiopathic nephrotic syndrome shows differences in its steroid response pattern and histopathological spectrum in the various geographical regions. ${ }^{8-16}$ Therefore, this work was designed to study the clinical profile, steroid response pattern and the underlying histopathological spectrum in children with INS at our locality in Upper Egypt. Sohag City is about $\mathbf{5 0 0} \mathrm{Km}$ South to Cairo city and Sohag University Hospital is a referral hospital serves patients from all Upper Egypt Governorates.

\section{Patients and methods}

This prospective study involved $\mathbf{7 7}$ patients with new onset INS aged 1-15 years diagnosed and followed in our paediatric nephrology unit, Sohag University Hospital in the period from Jan 2010 to Dec 2014. Patients with less than one year follow up period or with incomplete data were excluded. Idiopathic nephrotic syndrome was diagnosed depending on the presence of nephrotic range proteinuria $>\mathbf{4 0}$ $\mathrm{mg} / \mathrm{h} / \mathrm{m}^{2}$ or protein/creatinine ratio (uPCR) $>\mathbf{2} \mathrm{g} / \mathrm{g}$ and hypoalbuminemia $<25 \mathrm{~g} / \mathrm{l}$ with or without edema in the absence of systemic or extrarenal disorders. ${ }^{17,18}$ In addition to full medical history and detailed physical examination, the following investigations were done for all patients at presentation: urine analysis by dipsticks and microscopy, urine 24hours proteins or first morning uPCR, serum total protein and albumin, blood urea nitrogen, serum creatinine, total serum cholesterol and triglyceride, full blood count, serum electrolytes, Complement 3 (C3) and abdominal sonography. Antinuclear antibodies (ANA) test was done for patients more than 10 years old at disease onset. ${ }^{\mathbf{1 8 , 1 9}}$

The patients were divided into $\mathbf{3}$ age groups: preschool age (1-6 years), school age (6-12 years) and adolescence (12-15). Steroid (prednisone) was given to all patients in a dose of $2 \mathrm{mg} / \mathrm{kg} /$ day, for 4-6 weeks, followed by $1.5 \mathrm{mg} / \mathrm{kg}$ on alternate days for 4-6 weeks then gradually withdrawn over 2-5 months. ${ }^{17,20}$ The following definitions were used to categorize the steroid response patterns: complete remission (proteinuria $<4 \mathrm{mg} / \mathrm{h} / \mathrm{m}^{2}$, 0-trace on Albustix or uPCR $<\mathbf{0 . 2}$ g/g); partial remission (proteinuria reduction of $\mathbf{5 0 \%}$ or greater from the presenting value and absolute uPCR between $\mathbf{0 . 2}-$ $2 \mathrm{~g} / \mathrm{g}$ ); steroid response (remission with steroid therapy); relapse (nephrotic range proteinuria for $\mathbf{3}$ consecutive days after having been in remission); frequent relapses $(\geq \mathbf{2}$ relapses within $\mathbf{6}$ months of initial response or $\mathbf{Z} \mathbf{4}$ relapses within a period of 12 months); steroid dependence (2 consecutive relapses during steroid therapy or within $\mathbf{1 4}$ days after cessation of successful steroid therapy); steroid resistance (failure to achieve remission after $\mathbf{8}$ weeks of steroid therapy); initial steroid resistant (steroid resistance during the first episode); late steroid resistance (persistent proteinuria during $\geq \mathbf{4}$ weeks of steroid following one or more remissions). ${ }^{17,20,21}$

Renal biopsy was indicated at presentation for patients with atypical features (age >10 years, persistent hypertension, gross hematuria, renal impairment not attributable to hypovolemia or low C3) and following therapy initiation for patients with initial or late SRNS and those with SDNS or FRNS before treatment with cyclosporine A (CsA). ${ }^{17,19,22}$ Informed written consent was taken from the parents before the procedure and the specimens were examined by the same pathologist using light microscopy.

Statistical package for the social sciences (SPSS) version 16 was used 
for data analysis. Quantitative variables were presented as mean \pm standard deviation. Frequency and percentage were used for qualitative variables. For estimation of differences between qualitative variables, Chisquare and Fisher Exact Test were used. $\boldsymbol{P}$ values less than $\mathbf{0 . 0 5}$ were considered significant.

This study was approved by the ethical committee of Sohag University

\section{Results}

The total studied patients were 77 (47 males and $\mathbf{3 0}$ females) with male/female ratio 1.6/1. Mean age of patients at disease onset was 4.87 \pm 2.94 (range 1.5-15) years, with peak incidence at 1-6 years representing $\mathbf{7 1 . 4 \%}$ of total patients. The mean follow up duration was 2.30 $\pm \mathbf{1 . 1 5}$ (range 1-5) years. Initial hematuria was detected in 20 (26\%) patients with gross hematuria in $2 \mathbf{2 . 6 \%}$ ) patients and microscopic hematuria in $\mathbf{1 8}$ $\mathbf{2 3 . 4 \%}$ ) patients. Initial hypertension was found in $14 \mathbf{( 1 8 . 2 \% )}$ patients. Initial renal impairment was present in $\mathbf{2} \mathbf{( 2 . 6 \% )}$ patients which improved later on. Steroid therapy was given to all patients, of whom, 61 (79.2\%) achieved remission and $16(\mathbf{2 0 . 8 \%})$ were steroid resistant (table 1).

Table (1): Steroid response pattern and its relation to age, sex, initial hematuria and initial hypertension in studied patients

\begin{tabular}{|c|c|c|c|c|c|c|c|}
\hline \multirow[b]{3}{*}{ Variables } & \multicolumn{4}{|c|}{ Steroid response } & \multirow{3}{*}{ P-value } & \multirow{2}{*}{\multicolumn{2}{|c|}{ Total }} \\
\hline & \multicolumn{2}{|c|}{ Steroid sensitive } & \multicolumn{2}{|c|}{ Steroid resistant } & & & \\
\hline & No & $\%$ & No & $\%$ & & No & $\%$ \\
\hline Frequency & 61 & $79.2 \%$ & 16 & $20.8 \%$ & & 77 & $100 \%$ \\
\hline $\begin{array}{l}\text { Age groups } \\
\text { 1-6 years } \\
\text { 6-12 years } \\
12-15 \text { year }\end{array}$ & $\begin{array}{l}41 \\
19 \\
1\end{array}$ & $\begin{array}{l}74.5 \% \\
100 \% \\
33.3 \%\end{array}$ & $\begin{array}{l}14 \\
0 \\
2\end{array}$ & $\begin{array}{l}25.5 \% \\
0 \\
66.7 \%\end{array}$ & & $\begin{array}{l}55 \\
19 \\
3\end{array}$ & $\begin{array}{l}71.4 \% \\
24.7 \% \\
3.9 \%\end{array}$ \\
\hline $\begin{array}{l}\text { Sex } \\
\quad \text { Males } \\
\text { Females }\end{array}$ & $\begin{array}{l}37 \\
24 \\
\end{array}$ & $\begin{array}{l}\mathbf{7 8 . 7 \%} \\
80 \%\end{array}$ & $\begin{array}{l}10 \\
6 \\
\end{array}$ & $\begin{array}{l}21.3 \% \\
20 \%\end{array}$ & 0.893 & $\begin{array}{l}47 \\
30 \\
\end{array}$ & $\begin{array}{l}61 \% \\
39 \% \\
\end{array}$ \\
\hline Hematuria & 12 & $19.7 \%$ & 8 & $50 \%$ & 0.019 & 20 & $26 \%$ \\
\hline Hypertension & 5 & $8.2 \%$ & 9 & $56.2 \%$ & 0.000 & 14 & $18.2 \%$ \\
\hline
\end{tabular}

Out of 61 steroid sensitive patients, $5(8.2 \%)$ had no or only one relapse, 21 (34.4\%) had infrequently relapsing nephrotic syndrome (IRNS), 27 (44.3\%) developed SDNS, $\mathbf{6}(\mathbf{9 . 8 \%})$ developed FRNS and $\mathbf{2}(\mathbf{3 . 3} \%)$ developed late SRNS.

Renal biopsy was done in $\mathbf{2 6}(\mathbf{3 3 . 8 \%})$ patients. The indications for biopsy were: initial SRNS in 14 (53.8\%) patients, SDNS and FRNS before CsA use in 4 (15.4\%), late SRNS in $2(\mathbf{7 . 7 \%})$ and initial atypical presentation in $\mathbf{6}(\mathbf{2 3 . 1 \% )}$ patients. The main histopathological type was FSGS (figure 1). The relations of histopathology with the patients' clinical profile and steroid response are shown in table (2). 
SOHAG MEDICAL JOURNAL Patterns of idiopathic nephrotic syndrome in Upper Egyptian

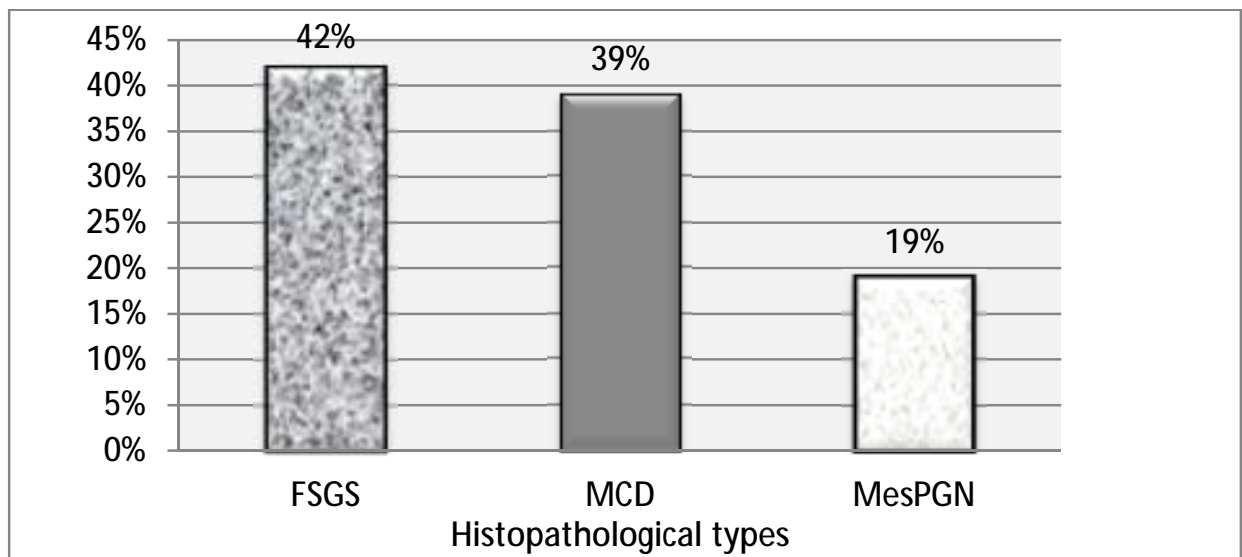

Figure (1): Histopathological spectrum of biopsied patients (FSGS, focal segmental glomerulosclerosis; MCD, minimal change disease; MesPGN, mesangioproliferative glomerulonephritis)

By the end of the study, persistent proteinuria (no or partial remission) was present in $10(13 \%)$ patients (7 with FSGS and 3 with MCD). One (1.3\%) patient with FSGS and multi-drug resistance developed ESRD. Death occurred in $\mathbf{2} \mathbf{( 2 . 6 \% )}$ patients (one with MCD and the other with FSGS), both were difficult multi-drug resistant cases. The causes of death were sepsis and ESRD.

Table (2): Histopathology in relation to clinical profile and steroid response

\begin{tabular}{|c|c|c|c|c|c|c|c|}
\hline \multirow[b]{3}{*}{ Variables } & \multicolumn{6}{|c|}{ Histopathology } & \multirow{3}{*}{ Total } \\
\hline & \multicolumn{2}{|c|}{ FSGS } & \multicolumn{2}{|c|}{ MCD } & \multicolumn{2}{|c|}{ MesPGN } & \\
\hline & No & $\%$ & No & $\%$ & $\begin{array}{l}\mathbf{N} \\
\mathbf{0}\end{array}$ & $\%$ & \\
\hline Frequency & 11 & $42 \%$ & 10 & $39 \%$ & 5 & $19 \%$ & 26 \\
\hline $\begin{array}{c}\text { Age groups } \\
1-6 \text { years } \\
6-12 \text { years } \\
12-15 \text { year } \\
\end{array}$ & $\begin{array}{l}8 \\
1 \\
2\end{array}$ & $\begin{array}{l}45 \% \\
16 \% \\
100 \% \\
\end{array}$ & $\begin{array}{l}6 \\
4 \\
0\end{array}$ & $\begin{array}{l}33 \% \\
68 \% \\
0\end{array}$ & $\begin{array}{l}4 \\
1 \\
0\end{array}$ & $\begin{array}{l}22 \% \\
16 \% \\
0\end{array}$ & $\begin{array}{l}18 \\
6 \\
2 \\
\end{array}$ \\
\hline $\begin{array}{l}\text { Sex } \\
\quad \text { Males } \\
\text { Females }\end{array}$ & $\begin{array}{l}5 \\
6\end{array}$ & $\begin{array}{l}\mathbf{3 3 \%} \\
\mathbf{5 5 \%}\end{array}$ & $\begin{array}{l}7 \\
3\end{array}$ & $\begin{array}{l}47 \% \\
27 \%\end{array}$ & $\begin{array}{l}3 \\
2\end{array}$ & $\begin{array}{l}20 \% \\
18 \%\end{array}$ & $\begin{array}{l}15 \\
11\end{array}$ \\
\hline $\begin{array}{l}\text { Hematuria } \\
\text { Gross } \\
\text { Microscopic }\end{array}$ & $\begin{array}{l}7 \\
1 \\
4\end{array}$ & $\begin{array}{l}45 \% \\
9 \% \\
36 \% \\
\end{array}$ & $\begin{array}{l}4 \\
0 \\
4\end{array}$ & $\begin{array}{l}40 \% \\
0 \\
40 \% \\
\end{array}$ & $\begin{array}{l}4 \\
\mathbf{1} \\
\mathbf{3}\end{array}$ & $\begin{array}{l}80 \% \\
20 \% \\
60 \% \\
\end{array}$ & $\begin{array}{l}15 \\
2 \\
13 \\
\end{array}$ \\
\hline Hypertension & 8 & $73 \%$ & 1 & $10 \%$ & 2 & $40 \%$ & 11 \\
\hline Renal impairment & 2 & $18 \%$ & $\mathbf{0}$ & $\mathbf{0}$ & $\mathbf{0}$ & $\mathbf{0}$ & 2 \\
\hline Steroid resistance & 9 & $82 \%$ & 4 & $40 \%$ & 3 & $60 \%$ & 16 \\
\hline $\begin{array}{l}\text { Persistent } \\
\text { proteinuria }\end{array}$ & 7 & $64 \%$ & 3 & $30 \%$ & $\mathbf{0}$ & $\mathbf{0}$ & 10 \\
\hline
\end{tabular}

FSGS, focal segmental glomerulosclerosis; MCD, minimal change disease;

MesPGN, mesangio-proliferative glomerulonephritis 


\section{Discussion}

Idiopathic nephrotic syndrome was most commonly seen in children 1-6 years old representing $\mathbf{7 1 . 4 \%}$ of patients, with male predominance in agreement with most previous studies as in Egypt $^{\mathbf{8}}, \operatorname{Iran}^{\mathbf{1 3}}$ and New Zealand. ${ }^{\mathbf{1 5}}$ Steroid was given to all included patients, with $\mathbf{7 9 . 2 \%}$ achieved remission while $\mathbf{2 0 . 8 \%}$ were steroid resistant (SR). Kaddah et al. in Cairo, Egypt showed that $\mathbf{3 4 \%}$ of their patients had SRNS, which was explained by high consanguinity according to the authors' explanation. ${ }^{8}$ In addition to this Kaddah et al. study revealed higher rate of MesPGN than ours. Lower steroid resistance was encountered in Yemen (7.1\%). ${ }^{\mathbf{1 2}}$ Near results were encountered in Saudia Arabia (21.4\%), Turkey (18\%) and New Zealand $\mathbf{( 1 9 . 6 \% ) .}{ }^{\mathbf{1 0 , 1 4 , 1 5}}$ Higher results were detected in Iran $\mathbf{( 2 4 . 8 \%}$ ), Brazil (29.9\%) and Japan (36\%). ${ }^{\mathbf{1 3 , 2 3 , 2 4}}$ The underlying renal histology in addition to ethnicity and geographic location have important impact on the likelihood of steroid response in INS. ${ }^{25}$ Variation in the definitions of SRNS and the involved age groups in the different centers also affect the results of various studies. About $\mathbf{5 4 \%}$ of the steroid sensitive patients developed either SDNS or FRNS in this study. Lower results were encountered in Iraq $(43.7 \%))^{11}$ Near results were reported in Denmark (56\%) and New Zealand $\mathbf{( 5 6 . 7 \% ) . ~}{ }^{\mathbf{2 6}, 15}$ Higher results were seen in Saudia Arabia (62\%) and France $(68 \%)^{10,27}$

Renal biopsy was indicated mainly for initial and late SRNS $(\mathbf{6 1 . 5 \%})$ in this work. This was in agreement with Kaddah et al. in Cairo, Bakr et al. in Almansoura, Mortazavi et al. in Iran and Arif et al. in India as steroid resistance was the main indication for renal biopsy in their studies. ${ }^{\mathbf{8 , 9 , 1 3 , 2 8}}$ The main histopathological type in our biopsied patients was FSGS in $\mathbf{4 2 \%}$, followed by $\mathrm{MCD}$ in $\mathbf{3 9 \%}$ and MesPGN in $19 \%$ of patients. Differences between our study and other studies in distribution of histopathological types are shown in table (3)

Table (3): Histopathological spectrum in the various studies

\begin{tabular}{|c|c|c|c|c|c|c|}
\hline & \multicolumn{5}{|c|}{ Histopathological patterns } & \multirow[b]{2}{*}{ Others } \\
\hline Studies & MCD & FSGS & MesPGN & MPGN & MN & \\
\hline $\begin{array}{l}\text { Our study } \\
\text { (Upper Egypt) }\end{array}$ & $39 \%$ & $42 \%$ & $19 \%$ & $\mathbf{0}$ & $\mathbf{0}$ & $\mathbf{0}$ \\
\hline $\begin{array}{l}\text { Kaddah et al, 2011 } \\
\text { (Lower Egypt) }\end{array}$ & $35 \%$ & $30 \%$ & $37 \%$ & $\mathbf{0}$ & $3 \%$ & $\mathbf{0}$ \\
\hline $\begin{array}{l}\text { Bakr et al, 2014 } \\
\text { (Lower Egypt) }\end{array}$ & $54.3 \%$ & $16.2 \%$ & $23.7 \%$ & $5.3 \%$ & 0.5 & $\mathbf{0}$ \\
\hline $\begin{array}{l}\text { Kari, 2002 } \\
\text { (Saudia Arabia) }\end{array}$ & $15 \%$ & $35 \%$ & $20 \%$ & $30 \%$ & $\mathbf{0}$ & $\mathbf{0}$ \\
\hline $\begin{array}{l}\text { Asinobi et al, } \text { 2015 }^{(30)} \\
\text { (Nigeria) }\end{array}$ & $19 \%$ & $47.6 \%$ & $\mathbf{0}$ & $19 \%$ & $\mathbf{0}$ & $14.4 \%$ \\
\hline $\begin{array}{l}\text { Mortazavi et al, } \text { 2011 }^{(13)} \\
\text { (Iran) }\end{array}$ & $40.8 \%$ & $32.7 \%$ & $26.5 \%$ & $\mathbf{0}$ & $\mathbf{0}$ & $\mathbf{0}$ \\
\hline $\begin{array}{l}\text { Mubarak et al, 2009 } \\
\text { (Pakistan) }\end{array}$ & $43.8 \%$ & $38.1 \%$ & $4.8 \%$ & $3.1 \%$ & $7.9 \%$ & $1.5 \%$ \\
\hline $\begin{array}{l}\text { Arif et al, } 2016^{(28)} \\
\text { (India) }\end{array}$ & $25 \%$ & $46.8 \%$ & $5.3 \%$ & $5.3 \%$ & $14.7 \%$ & $2.6 \%$ \\
\hline $\begin{array}{l}\text { Zhou et al, 2014 } \\
\text { (China) }\end{array}$ & $11.5 \%$ & $16.5 \%$ & $48.2 \%$ & $4.6 \%$ & $3.6 \%$ & $15.6 \%$ \\
\hline
\end{tabular}


MCD, minimal change disease; FSGS, focal segmental glomerulosclerosis; MesPGN, mesangio-proliferative glomerulonephritis; MPGN, membranoproliferative glomerulonephritis; $\quad$ MN, membranous nephropathy

The noticed variations in the histopathological results among and the studies were not done in the same time periods.

In conclusion the demographic features of INS in our locality were comparable to those worldwide with its predominance in young age and male sex. Inspite of high response rate in INS more than half of steroid sensitive patients developed steroid dependent

\section{References}

\section{McCaffrey J, Lennon R, Webb NJ} (2016) The non-immunosuppressive management of childhood nephrotic syndrome. Pediatr Nephrol 31:13831402

2. Chanchlani R, Parekh RS (2016) Ethnic Differences in Childhood Nephrotic Syndrome. Frontiers in Pediatrics 4:39

3. Pais P, Avner ED: Nephrotic syndrome. In: Kliegman RM, Stanton BF, Geme JW, Schor NF editors: Nelson Textbook of pediatrics, 20th ed, Philadelphia, Elsevier Inc, 2016; 527:2521-2527.

4. Larkins N, Kim S, Craig J, Hodson E (2016) Steroid-sensitive nephrotic syndrome: an evidence-based update of immuno-suppressive treatment in children. Archives of Disease in Childhood 101(4):404-440

5. Sureshkumar P, Hodson EM, Willis NS, Barzi F, Craig JC (2014) Predictors of remission and relapse in idiopathic nephrotic syndrome: a prospective cohort study. Pediatr Nephrol 29:1039-1046

6. ISKDC (International study of Kidney Disease in Children) 1981 The primary nephrotic syndrome in children: Identification of patients different studies in various countries reflect the differences present in renal biopsy practices in different centers in addition to variabilities in ethnic background and environmental circumstances. Beside to this, the involved groups in these studies do not have the exact age limits as each other

or frequently relapsing course. Steroid resistance was the main indication for renal biopsy and FSGS was the most prominent histopathological type in our biopsied patients.

Financial support: None.

Conflict of interest statement: None declared

with minimal change nephrotic syndrome from initial response to prednisone. A report of the International Study of Kidney Disease in Children. J Pediatr 98(4):561-564

7. Ishikura K, Matsumoto S, Sako M, Tsuruga K, et al (2015) Clinical practice guideline for pediatric idiopathic nephrotic syndrome 2013: medical therapy. Clin Exp Nephrol 19:6-33

8. Kaddah A, Sabry S, Emil E, ElRefaey M (2012) Epidemiology of primary nephrotic syndrome in Egyptian children. J Nephrol 25 (05):732-737

9. Bakr A, Eid R, Sarhan A, Hammad A, El-Refaey AM, et al (2014) Pathological profile of biopsied Egyptian children with primary nephrotic syndrome: 15-year single center experience. J Nephrol 27(4):419-423

10. Alharthi AA (2016) Patterns of Childhood Steroid-Sensitive and Steroid-Resistant Nephrotic Syndrome in Saudi Children: Clinicopathological Study of $\mathbf{8 7}$ Cases. Clinical Pediatrics 1-7. DOI: 10.1177/0009922816645521 
11. Ali SH, Ali AM, Najim AH (2016) The Predictive Factors for Relapses in Children with Steroid-Sensitive Nephrotic Syndrome. Saudi J Kidney Dis Transpl 27(1):67-72

12. Bin-Mohanna $M$, Bin Alzoa $A$ (2014) Pediatric Idiopathic Nephrotic Syndrome in Al-Sabeen Hospital Sana'a City-Yemen. Hadhramout Journal of Medical Sciences (HJMS) 3(1,2):239-242

13. Mortazavi F, Khiavi YS (2011) Steroid response pattern and outcome of pediatric idiopathic nephrotic syndrome: a single-center experience in northwest Iran. Therapeutics and Clinical Risk Management 7:167171

14. Hacıhamdioğlu DÖ, Kalman S, Gök F (2015) Long-term results of children diagnosed with idiopathic nephrotic syndrome; single center experience. Türk Ped Arş 50:37-44

15. Wong W (2007) Idiopathic nephrotic syndrome in New Zealand children, demographic, clinical features, initial management and outcome after twelve-month followup: Results of a three-year national surveillance study. Journal of Paediatrics and Child Health 43:337341

16. Zhou TB, Lin N, Qin YH, Liu YG (2014) Distribution of Pathological Finding in the Children with Nephrotic Syndrome from Guangxi. Saudi J Kidney Dis Transpl 25(3):684-688

17. Niaudet $P$, Boyer O: Idiopathic nephrotic syndrome in childhood: clinical aspects. In: Avner ED, Harmon WE, Niaudet P, Yoshikawa $\mathrm{N}$ editors: Pediatric Nephrology. 6th ed. Germany: Springer-Verlag, 2009; 667-702.

18. Pais, Ellis, Avner ED: Nephrotic syndrome. In: Kliegman RM, Stanton BF, Geme JW, Schor NF, Behrman RE, editors: Nelson Textbook of pediatrics 19th ed,
Philadelphia, Elsevier Saunders, 2011; 521:1801-1807.

19. Bagga A (2008) Revised guidelines for management of steroid-sensitive nephrotic syndrome. Indian J Nephrol 18(1):31-39

20. KDIGO (Kidney Disease Improving Global Outcomes)

Glomerulonephritis Work Group 2012: KDIGO clinical practice guideline for glomerulonephritis. Kidney Int Suppl 2:139-274

21. Gipson DS, Massengill SF, Yao L, Nagaraj S, Smoyer WE, Mahan JD, et al (2009) Management of childhood onset nephrotic syndrome. Pediatrics 124(2):747-757

22. Valentini RP, Smoyer WE: Nephrotic syndrome. In: Kher KK, Schnaper HW, Makker SP, editors: Clinical Pediatric Nephrology. Second edition, Informa Healthcare, 2007; 11:155-194.

23. Mendonça AC, Oliveira EA, Fróe BP, Faria LD, et al (2015) A predictive model of progressive chronic kidney disease in idiopathic nephrotic syndrome. Pediatr Nephrol 30:2011-2020

24. Inaba A, Hamasaki $Y$, Ishikura $K$, Hamada R, Sakai T, et al (2016) Long-term outcome of idiopathic steroid-resistant nephrotic syndrome in children. Pediatr Nephrol 31:425434

25. Gbadegesin R, Gibson KL, Smoyer WE: Steroid resistant Nephrotic Syndrome. In: Geary DF, Schaefer F Editors: Pediatric Kidney Disease, Second Edition, Springer-Verlag Berlin Heidelberg 2016; 16:455-478.

26. Andersen RF, Thrane N, Noergaard K, Rytter L, Jespersen B, Rittig S (2010) Early age at debut is a predictor of steroid-dependent and frequent relapsing nephrotic syndrome. Pediatr Nephrol 25(7):1299-1304

27. Letavernier $\mathbf{B}$, Letavernier $\mathbf{E}$, Leroy S, Baudet-Bonneville V, 
Bensman A, Ulinski T (2008)

Prediction of high-degree steroid dependency in pediatric idiopathic nephrotic syndrome. Pediatr Nephrol 23(12):2221-2226

28. Arif MK, Arif M, Amjad N (2016)

A histopathological outlook on nephrotic syndrome: A pediatric perspective. Indian J Nephrol 26(3):188-191

29. Kari JA (2002) Changing trends of histopathology in childhood nephrotic syndrome in western Saudia Arabia. Saudia Med J 23:317-321
30. Asinobi AO, Ademola AD, Okolo CA, Yaria JO (2015) Trends in the histopathology of childhood nephrotic syndrome in Ibadan Nigeria: preponderance of idiopathic focal segmental glomerulosclerosis. BMC Nephrology 16:213

31. Mubarak M, Lanewala A, Kazi JI, Akhter F, Sher A, Fayyaz A, Bhatti S (2009) Histopathological spectrum of childhood nephrotic syndrome in Pakistan. Clin Exp Nephrol 13(6):589-593 